IJ§ER

ISSN: 2149-5939
International Journal of Social Sciences and Education Research

Online, http://dergipark.gov.tr/ijsser

Volume: 3(5), 2017

\title{
Turkish EFL lecturers' perceptions regarding the essentials in a high-qual- ity foreign language education
}

\author{
Birgül Akdağ Çimen ${ }^{1}$
}

Received Date: 29 / 06 / 2017

Accepted Date: 20 / 09 / 2017

\begin{abstract}
This qualitative study investigated Turkish EFL lecturers' views about vital components of a high-quality foreign language education with desirable results. For this purpose, written answers to open-ended interview questions were collected from 15 voluntary EFL lecturers who were working for the same university in the 2016-2017 academic year. The content analysis of the qualitative data revealed four main factors that are believed to be essential for a good EFL education. These categories included effective teaching practices, certain student and teacher characteristics as well as external factors such as physical conditions of classrooms. An overall analysis of the qualitative data showed that the participants' perceptions comply with five of the seven principles by Chickering and Gamson (1987).
\end{abstract}

Keywords: EFL lecturers, EFL education, perceptions, high-quality education, seven principles

\section{Introduction}

Since the universities started to accept higher number of students a few decades ago, undergraduate education classrooms have been increasingly diversified and the quality of education has been the main concern for educators (Biggs \& Tang, 2011). Foreign language education, on the other hand, has been gaining popularity since the beginning of globalisation which puts the quality of foreign language education top on the priority list across the world. The importance of foreign language education has called for additional research to identify certain indicators of good educational practices. The purpose of the study was to examine Turkish EFL lecturers' understanding of the essentials of a high-quality foreign language education within the framework of seven principles by Chickering and Gamson (1987).

\section{Literature review}

Chickering and Gamson (1987), with an aim to provide a set of principles that guide high quality undergraduate education. The principles they offered as a framework included studentfaculty contact, cooperative learning, active learning, prompt feedback, communication of high expectations, and respect for diverse talents and ways of learning.

The first principle, student-faculty contact, holds that interactions that occur between students and faculty improve students' motivation level and enhances their learning process (Chickering \& Gamson, 1987). Previous studies confirm the positive impact of a healthy dose of studentfaculty interaction on learners. A recent study by Varghese (2016), for example, revealed a significant relationship between the amount of student-faculty interactions taking place and the participants' learning experiences. Another study conducted by Njoroge, Gichure, and Wang'eri

\footnotetext{
${ }^{1}$ Atatürk University, Erzurum, TURKEY badlybrokendoll@gmail.com 
Akdağ Çimen, B. (2017). Turkish EFL lecturers' perceptions regarding the essentials in a high-quality foreign language education. International Journal of Social Sciences and Education Research, 3(5), 1606-1615.

(2016) also yielded results in favour of student-faculty contact. According to the research findings, student attrition rate decreases in the presence of a high amount of student-faculty interactions.

The second principle emphasises the importance of cooperation among students (Chickering \& Gamson, 1987). As Slavin (1985) suggests, human beings are born into a system of cooperation and their survival depends on the cooperative groups that they belong to. Schools, in this sense, also need to be a place where people contribute to each other through cooperation. The recent popularity of Cooperative learning, therefore, has its roots in the habits formed over years. Cooperative learning favours teaching the whole classroom by letting students work in small groups. The main purpose is to encourage interaction between peers and help them contribute to each other's learning experiences (Johnson, Johnson, \& Smith, 2014). The previous studies including those of Zamani (2011) and Estaji \& Aghdam (2016) revealed the benefits of cooperative learning from various perspectives. In the former study, cooperative learning was suggested to benefit learners' academic achievement in an EFL writing class. In the latter, on the other hand, the findings pointed to an improvement in students' critical thinking abilities as a result of a 10-session treatment based on cooperative learning.

The third principle puts emphasis on the notion of active learning and is in favour of students who take the responsibility for their own achievement by reflecting on and actively using what they have learnt instead of passively receiving information (Chickering \& Gamson, 1987). Numerous studies have revealed the superiority of active learning over passive learning in terms of academic performance (e.g. Freeman, et al., 2014; Hung, 2015; Taylor, 2016). Of these studies, some were conducted in EFL learning context with similarly positive results. The research by Naderi and Ashraf (2013), for example, pointed to an enhancement in EFL learners' listening self-efficacy beliefs as a result of active learning strategies. Er, Altunay and Yurdabakan (2012), on the other hand, concluded that implementation of active learning strategies improve learners' EFL reading comprehension skills.

The next principle holds that providing learners with prompt feedback supports them in their learning process (Chickering \& Gamson, 1987). In this sense, showing students where they need additional help or work contributes to their achievement (Panther Bishoff, 2010). The findings of the study conducted by Nadeem and Nadeem (2013) confirm that the feedback students receive from their teachers is closely related to student behaviours in the classroom.

The scope of the fifth principle includes emphasising time on task. Learning a subject requires mental effort and time allocation (Chickering \& Gamson, 1987). Students need to allocate a certain amount of time to a certain task in order to comprehend it. Previous studies into the impact of time on task also reveal the link between time on task and schooling outcomes. Lavy (2012), for example, in his study, investigated time on task in relation to students' academic performance. The research findings revealed better academic achievement as a result of increased time on task. Acknowledging the importance of on task behaviours among students, Pate-Clevenger, Dusing, Houck, and Zuber (2008) carried out an action research project to find a way to decrease the time students spend off task. Their findings indicated an increase in learners' time on task behaviours when they are taught through cooperative learning strategies.

The sixth principle favours the communication of high expectations to students (Chickering \& Gamson, 1987). Previous research also confirms the benefits of high teacher expectancy for learners' overall academic success. A comprehensive study by Jackson (2005), for example, revealed 
Akdağ Çimen, B. (2017). Turkish EFL lecturers' perceptions regarding the essentials in a high-quality foreign language education. International Journal of Social Sciences and Education Research, 3(5), 1606-1615.

that the positive impact of high teacher expectancy on student achievement in maths course. The researcher concluded that teachers with high expectations for their students tend to put more effort in the choice of teaching methods and materials to keep students engaged. The findings of a recent study by Li (2014) also suggested differences in teaching practices in accordance with teacher expectancy.

The last principle holds that teachers should respect students' diverse talents and learning styles (Chickering \& Gamson, 1987). The suggestion is to pay attention to variety of learning preferences and choose classroom activities and teaching materials accordingly to maximise student learning (Duhart, Ortiz \& Rodriguez, 2016). As the study by Tulbure (2011) suggests, learners perform better when the whole teaching process is in harmony with their learning preferences. Therefore, the key is to incorporate a wide range of activities that suit diverse learner needs and learning styles.

\section{Methodology}

\subsection{Participants}

This study took place in the second term of 2016-2017 academic year and followed qualitative research design to address the participants' perceptions about the essentials of a high-quality foreign language education. The participants of the study included 15 EFL lecturers currently working for the same university in the eastern part of Turkey. The lecturers that participated in the study were randomly selected, and each was informed that participation was not compulsory.

\subsection{Instrument}

To obtain the participants' insights about the Essentials of high-quality foreign language education, a total of 5 open-ended questions were prepared by the researcher. All of these questions saught information about their understanding and beliefs about the vital components of foreign language education to maximise learning outcomes. The participants provided their answer in written form.

\subsection{Data collection and analysis}

The participants were handed the open-ended questions and were given time to answer all of them by paying attention to each question. They were asked to return their answer in a two-week time period. The purpose was to help them focus on their answers without hurrying to finish in a short time.

The obtained data, on the other hand, were analysed through content analysis. For this, th researcher went through the written data over and over to define codes and categories in relation to the theme. The analysis revealed four categories that were vital for high-quality foreign language education. These categories included Effective teaching practices, Student characteristics, Teacher characteristics, and External factors.

\section{Result and discussion}

The theme included detailed information regarding the participants' perceptions about high quality foreign language teaching. The first category in the theme revealed that for more than half of the participants benefiting from various and appropriate teaching materials plays an important role in foreign language education. P7 noted that 'a careful selection of materials and textbooks 
Akdağ Çimen, B. (2017). Turkish EFL lecturers' perceptions regarding the essentials in a high-quality foreign language education. International Journal of Social Sciences and Education Research, 3(5), 1606-1615.

boosts the learning outcomes'. The participants also agreed that including various types of materials, particularly audio-visual ones, benefit learners the most by appealing to different senses. Increasing the range of materials to be used is one of the most effective ways to deal with various learner needs and foster their learning equally (Guild, 1980; Yassin \& Almasri, 2015).

The content analysis of the data revealed the following theme, codes, and categories.

Table 1. Theme: Essentials of good foreign language teaching

\begin{tabular}{|c|c|c|}
\hline & & $\mathbf{N}$ \\
\hline \multirow{13}{*}{$\begin{array}{l}\text { Category \# } 1 \\
\text { Student- }\end{array}$} & $\begin{array}{l}\text { Incorporating various and appropriate teaching mate- } \\
\text { rials }\end{array}$ & 8 \\
\hline & Having plenty of time for language practice & 7 \\
\hline & Focus on four basic language skills & 6 \\
\hline & Providing feedback to learners & 4 \\
\hline & Benefiting from technological facilities & 4 \\
\hline & Encouraging interaction in classroom & 3 \\
\hline & Encouraging out of class learning & 3 \\
\hline & Less focus on grammar teaching & 3 \\
\hline & Providing learner-centred education & 3 \\
\hline & Setting clear and realistic learning goals & 2 \\
\hline & Encouraging cooperation among learners & 2 \\
\hline & Encouraging active learning & 2 \\
\hline & Respecting diverse talents and learning styles & 1 \\
\hline \multirow{2}{*}{$\begin{array}{l}\text { Category \# } 2 \\
\text { Student Characteristics }\end{array}$} & Willing and motivated students & 7 \\
\hline & Awareness of foreign language learning & 4 \\
\hline \multirow{2}{*}{$\begin{array}{l}\text { Category \# } 3 \\
\text { Teacher Characteristics }\end{array}$} & Dynamic and caring teachers & 5 \\
\hline & High-quality teachers & 4 \\
\hline \multirow{3}{*}{$\begin{array}{l}\text { Category \# } 4 \\
\text { External Factors }\end{array}$} & Appropriate physical conditions & 4 \\
\hline & A carefully-designed curriculum & 1 \\
\hline & Non-compulsory English courses & 1 \\
\hline
\end{tabular}

The participants also mentioned the need for time allocated for language practice for efficient language learning. According to them, teachers and students should be in no hurry to achieve quick results because acquiring a language requires time and patience. As one of the participants (P2) stated, 'there needs to be enough number of courses and opportunities to practice the target language'. Encouraging interactions in the target language within classroom is one of the many ways to increase target language practice by students (Thomson, 2012; Moeller \& Roberts, 2013).

Another important point in foreign language education was mentioned to be a greater emphasis on the four basic language skills which include reading, writing, listening and speaking. For the participants, the focus should be on listening and speaking skills in the very beginning. A previous study conducted in Malaysia (Hassan \& Selamat, 2002) confirms the importance of practicing listening and speaking skills as the results attribute the participant students' low proficiency in English to the lack of practices of those two skills. There should be enough emphasis on all basic skills so that learners can improve their foreign language to be able to effectively communicate in it. 
Akdağ Çimen, B. (2017). Turkish EFL lecturers' perceptions regarding the essentials in a high-quality foreign language education. International Journal of Social Sciences and Education Research, 3(5), 1606-1615.

Four of the participants stressed the importance of providing effective feedback to learners. P15 commented that 'teachers should be aware of students' weak points and should provide highquality feedback to improve them'. The previous studies also point out that feedback can benefit learners in numerous ways including teacher-student interactions (Skipper \& Douglas, 2015; Lee $\&$ Schallert, 2008) and improved learning outcomes (Krause \& Stark, 2010). The participants also suggested that teachers should benefit from technological facilities while providing foreign language education. For them, Web 2.0 tools and social media can boost their learning from various aspects as is also suggested by the previous literature (e.g. Al-Rahmi, Othman \& Musa, 2014; Pattanapichet \& Wichadee, 2015).

For the participants, encouraging interactions in classroom and learning out of classroom are also important points in foreign language education. P1 describes the ideal teacher-student interaction as 'neither too close nor too official'. A healthy dose of high-quality interaction within classrooms can enhance student engagement (Rimm-Kaufman, Baroody, Larsen, Curby \& Abry, 2015) and increase their language proficiency when interactions occur in the target language (Tulung, 2008). The participants also added that teachers should provide a learner centred education with a less focus on grammar and encourage out of class learning because learning a language cannot take place within the physical limits of classrooms. The current understanding also suggests avoiding explicit grammar teaching and employing an eclectic approach to help students improve their basic language skills (Norris, 2016) and encouraging high-quality out of class EFL learning (Lai, Zhu \& Gong, 2015).

In addition, two of the participants mentioned the importance of setting clear and realistic goals for desirable learning outcomes. For them, both teachers and students should know what is expected of them and what they are trying to achieve. Besides, for P2, explaining goals and expectations in the very beginning helps with learner engagement throughout courses. An early study by Braun, Neilsen and Dykstra (1975) suggests that when teachers clearly express their expectations from their students and set learning goals, students' schooling outcomes as well as their social behaviours are more likely to thrive.

Cooperation among students and active learning almost always occur together. Two of the interviewees in the study emphasised that both active learning and cooperation among learners are essential in foreign language teaching. As P9 expressed,

Students should be active learners. They need to spend time on challenging tasks.

They should also engage in extra-curricular activities outside the classroom.

Teachers, on the other hand, need to encourage student participation through pair work, group work and activities that foster cooperation among learners.

Previous studies also confirm the benefits of both notions in education. Active learning is believed to improve critical thinking skills (Kim, Sharma, Land \& Furlong, 2012) as well as learning outcomes and interaction (Kalem \& Fer, 2003). According to several studies, on the other hand, cooperative learning increases interactions within classroom, enhances learners' social skills, and improves attitudes towards the course (Gömleksiz, 2007; Ning, 2013; Bilgin \& Geban, 2004).

Various learner styles and talents have been acknowledged in the field of education recently. One of the participants in the study (P6) stated that 'Teachers should respect diverse learning styles and should incorporate activities to encourage learners with various talents.' The power of education increases when teachers pay attention to their learners' learning preferences by offering 
Akdağ Çimen, B. (2017). Turkish EFL lecturers' perceptions regarding the essentials in a high-quality foreign language education. International Journal of Social Sciences and Education Research, 3(5), 1606-1615.

them a variety of educational activities to benefit from (Blevins, 2014; Ph'ng, Ming \& Nambiar, 2015).

The second category in the theme includes student characteristics that are believed to be essential in a high-quality foreign language education. Nearly half of the participants directly expressed that students' willingness determines their learning outcomes. Several studies also concluded that student motivation plays a great role in their achievement in school (e.g. Chiang, Yang, Huang \& Liou, 2014; Mega, Ronconi, De Beni, 2014; Walkey, McClure, Meyer \& Weir, 2013).

In addition to being motivated to learn, students should also be aware of the reasons why they are learning a foreign language to improve their motivation. Four of the participants mentioned the importance of foreign language awareness for learners. P12 summarised the issue as follows:

First of all, students should be aware of the reasons why they are really learning English. For them, English should be more than a course at school. Otherwise, they only memorise the vocabulary and focus on exams rather than communicative skills.

While most of the students learning EFL in other countries are aware of the fact that they will be actively using the target language for a good reason in their lives, students in Turkey seem to study English only to pass exams and they do not believe that they will need English for any other reasons (Deveci, 2016). For better engagement and increased motivation, learners should know exactly why they are taking English courses and how they can benefit from them.

Teacher characteristics also play an important role in the quality of foreign language education. Teachers determine the learning outcomes and learners proficiency in EFL to an extent (Lei, 2007). The characteristics of effective EFL teachers include respect for diverse learners, good technological skills, and effective teaching practices (Kourieos \& Evripidou, 2013). Teachers should also have friendly interactions with their students (Baytur \& Raz1, 2015) as no effective education is possible but for a high-quality teacher who cares for his students. Five of the participants in this study clearly noted that EFL teachers need to be dynamic and full of energy in courses to be able to keep students engaged and motivated. This result is highly compatible with the results of the study by Salahsour and Hajizadeh (2013) who list 'being enthusiastic and lively' as one of the many characteristics effective EFL teachers have.

Besides the above listed characteristics of effective EFL teachers, the quality of teacher training they receive is also highlighted by the participants of the present study. According to four of the participants, EFL teachers should be qualified to choose the most appropriate teaching methods and activities to meet their learners' needs, they need to be experts in their own fields and should know how to perform best even under undesirable conditions. For this, teachers should be supported and provided with additional professional development opportunities (DeMonte, 2013).

The final category includes the participants' perceptions regarding the eternal factors that affect the learning outcomes in foreign language education. The participants listed physical conditions of schools and classrooms as the most important external factor. Four of the participants, in this sense, noted that class size is extremely important. According to P11 'the physical environment should be carefully designed for foreign language teaching. For example, there should be 15 students at maximum in each class'. Various studies confirm the importance of optimal class 
Akdağ Çimen, B. (2017). Turkish EFL lecturers' perceptions regarding the essentials in a high-quality foreign language education. International Journal of Social Sciences and Education Research, 3(5), 1606-1615.

size for high-quality education. Bedard and Kuhn (2008), for example, conclude that class size affects learners' assessment of teacher effectiveness: the smaller the size, the higher ratings of teacher effectiveness.

One of the participants, on the other hand, commented that the curriculum affects the quality of foreign language education to a great degree because the curriculum guides teaching practices. This is especially because we still have standardised curriculum in Turkey. Apparently, standardised curriculum pays no attention to diverse learner needs in classroom (Saparani \& Perez, 2015).

Another participant noted that English should not be a compulsory course at tertiary level. According to him, students lose interest in English courses because they do not choose to have English courses. Others decide for them to take them. This comment takes us back to the importance of language awareness. Learners' motivation for learning English should come from their awareness of what they can do with what they have learnt. The study by Green and Fujita (2016) also implies that students have a more positive attitude towards EFL courses when they know they can personally benefit from them.

\section{Conclusion}

The results clearly show that for the participants of the study effective teaching practices are those that comply with especially five of the seven principles set by Chickering and Gamson (1987). That is, teachers need to respect diverse learning styles in classroom by resorting to various materials and activities, they need to provide feedback to their learners to help them improve, they need to encourage interaction in classroom particularly in the target language. Teachers should also encourage cooperation among learners so that they can benefit from each other without affective filters. Last but not least, for high-quality foreign language education, teachers should help their students become active learners who pursue their learning goals not only within classroom, but also out of it.

In addition, students should be motivated to learn and know what they are learning English for. Teachers, on the other hand, should keep their energy levels up in the classroom so that they can engage the students more. They should also work for their own personal development to keep up with the novelties in their field.

Finally, the findings of the study suggest that optimal class size is a must for a good foreign language education. Both students and teachers perform better when they are not reversely affected by the environment they are in. The curriculum should be designed to meet learners' needs, and English courses should not be compulsory.

\section{References}

Al-Rahmi, W.M. , Othman, M.S. and Musa, N.A. (2014), The improvement of students' academic performance by using social media through collaborative learning in Malaysian higher education, Asian Social Science, 10(8), 210-221.

Baytur, B., \& Raz1, S. (2015). Characteristics of effective EFL teachers from the perspective of Turkish EFL learners. International Journal of Human and Behavioral Science, 1(2), 1-9.

Bedard, K., \& Kuhn, P. (2008). Where class size really matters: Class size and student ratings of instructor effectiveness. Economics of Education Review, 27(3), 253-265.

Biggs, J., \& Tang, C. (2011). Teaching for Quality Learning At University. Open University Press/McGraw Hill Education, Newyork. 
Akdağ Çimen, B. (2017). Turkish EFL lecturers' perceptions regarding the essentials in a high-quality foreign language education. International Journal of Social Sciences and Education Research, 3(5), 1606-1615.

Bilgin, İ., \& Geban, Ö. (2004). Investigating the effects of cooperative learning strategy and gender on preservice elementary teacher students' attitude toward science and achievement of science teaching class I. Hacettepe University Education Faculty Journal,(26), 9-18.

Blevins, S. (2014). Understanding learning styles. Medsurg Nursing, 23(1), 59-60.

Braun, C., Neilsen, A. R., \& Dykstra, R. (1975). Teacher's Expectations: Prime Mover or Inhibitor?. The elementary school Journal, 76(3), 181-188.

Chiang, T. H., Yang, S. J., Huang, C. S., \& Liou, H. H. (2014). Student motivation and achievement in learning English as a second language using Second Life. Knowledge Management \& E-Learning: An International Journal (KM\&EL), 6(1), 1-17.

Chickering, A. W. \& Gamson, Z. F. (1987). Seven Principles for Good Practice in Undergraduate Education. AAHE Bulletin, 39, 3-7.

Çelebi, M. D. (2006). Türkiye’de anadili eğitimi ve yabanci dil öğretimi. Sosyal Bilimler Enstitüsü Dergisi, (21), 285-307.

Darling-Hamond, L. (2000). Teacher Quality and Student Achievement: A Review of State Policy Evidence. Education Policy Analysis Archives, 8(1), 1-44.

Deveci, C. (2016). 2nd, 3rd and 4th Grade Primary School Students' Awareness of Learning English. Master Thesis, Ataturk University, Erzurum.

DeMonte, J. (2013, July). High quality professional development for teachers. Washington, DC: Center for American Progress.

Duhart, A. R., Ortiz, J. F. Z., \& Rodríguez, A. L. (2016). Learning styles and their relationship with academic performance in English as a second language of students in a Mexican university. Journal of Learning Styles, 9(17), 108-143.

Er, M., Altunay, U. \& Yurdabakan, I. (2012). The effects of active learning on foreign language self-concept and reading comprehension achievement. International Journal for New Trends in Education and Their Implications, 3, 1309-6249.

Estaji, M., \& Moradi Aghdam, S. (2016). $\neg$ Employing a Cooperative Learning Technique as a Means to Promote Iranian EFL Learner's Critical Thinking. English Language Teaching, 3(2), 69-49.

Freeman, S., Eddy, S. L., McDonough, M., Smith, M. K., Okoroafor, N., Jordt, H., \& Wenderoth, M. P. (2014). Active learning increases student performance in science, engineering, and mathematics. Proceedings of the National Academy of Sciences, 111(23), 8410-8415.

Gömleksiz, M. N. (2007). Effectiveness of cooperative learning (jigsaw II) method in teaching English as a foreign language to engineering students (Case of Firat University, Turkey). European journal of engineering education, 32(5), 613-625.

Green, K., \& Fujita, J. (2016). Students of Different Subjects Have Different Levels of Extrinsic and Intrinsic Motivation to Learn English: Two Different Groups of EFL Students in Japan. English Language Teaching, 9(9), 156-165.

Guild, P. O. R. B. (1980). Learning styles: knowledge, issues and applications for classroom teachers. Unpublished Doctoral Dissertation, University of Massachusetts.

Hassan, F., \& Selamat, F. (2017). WHY AREN'T STUDENTS PROFICIENT IN ESL: THE TEACHERS'PERSPECTIVE. The English Teacher, 107-123. 
Akdağ Çimen, B. (2017). Turkish EFL lecturers' perceptions regarding the essentials in a high-quality foreign language education. International Journal of Social Sciences and Education Research, 3(5), 1606-1615.

Haznedar, B. (2010, November). Türkiye'de yabancı dil eğitimi: Reformlar, yönelimler ve öğretmenlerimiz. In International Conference on New Trends in Education and Their Implications, Antalya, Turkey. Retrieved from http://www. iconte. org/FileUpload/ks59689/File/166. pdf.

Hung, H. T. (2015). Flipping the classroom for English language learners to foster active learning. Computer Assisted Language Learning, 28(1), 81-96.

Jackson, M. (2005). An Investigation of The Relationship Between Teacher Expectations and Student Achievement: A Focus on Mathematics In Urban Public Schools. Unpublished Doctoral Dissertation. Wayne State University, Detroit, Michigan.

Johnson, D. W., Johnson, R. T., \& Smith, K. A. (2014). Cooperative learning: Improving university instruction by basing practice on validated theory. J. on Excellence in University Teaching, 25(4), 1-26.

Kalem, S., \& Fer, S. (2003). The effects of active learning model on the learning, teaching and communication process of students. Educational Sciences Theory \& Practice, 3(2), 433-461.

Kim, K., Sharma, P., Land, S. M., \& Furlong, K. P. (2013). Effects of active learning on enhancing student critical thinking in an undergraduate general science course. Innovative Higher Education, 38(3), 223-235.

Kourieos, S., \& Evripidou, D. (2013). Students' perceptions of effective EFL teachers in university settings in Cyprus. English Language Teaching, 6(11), 1-16.

Krause, U. M., \& Stark, R. (2010). Reflection in example-and problem-based learning: Effects of reflection prompts, feedback and cooperative learning. Evaluation \& research in education, 23(4), 255-272.

Lai, C., Zhu, W., \& Gong, G. (2015). Understanding the quality of out-of-class English learning. TESOL Quarterly, 49(2), 278-308.

Lavy, V. (2012). Expanding School Resources and Increasing Time on Task: Effects on Student's Academic Achievements, and Non-cognitive Outcomes. Maurice Falk Institute for Economic Research in Israel. Discussion paper series., (11), Retrieved on 11.04.2017 from http://www.nber.org/papers/w18369.pdf

Lee, G., \& Schallert, D. L. (2008). Constructing trust between teacher and students through feedback and revision cycles in an EFL writing classroom. Written Communication, 25(4), 506-537.

Lei, Q. (2007). EFL Teachers' Factors and Students' Affect. Online Submission, 4(3), 60-67.

Li, Z. (2014). Teachers matter: Expectation effects in foreign language classrooms at university. Unpublished Doctoral Dissertation, University of Auckland.

Mega, C., Ronconi, L., \& De Beni, R. (2014). What makes a good student? How emotions, self-regulated learning, and motivation contribute to academic achievement. Journal of Educational Psychology, 106(1), 121-131.

Moeller, A.J. \& Roberts, A. (2013). Keeping it in the target language. 2013 Report of the Central States Conference on the Teaching of Foreign Languages, 21-38.

Naderi, S., \& Ashraf, H. (2013). The Effect of Active Learning Instruction on the Intermediate Iranian EFL Learners' Listening Self-Efficacy Beliefs. International Journal of Linguistics, 5(6), 91-109.

Ning, H. (2013). The impact of cooperative learning on English as a foreign language tertiary learners' social skills. Social Behavior and Personality: an international journal, 41(4), 557-567.

Njoroge, M. M., Gichure, C., \& Wang'eri, T. (2016). Role of student faculty interaction in attrition among students in private universities in Nairobi county, Kenya. Journal of Emerging Trends in Educational Research and Policy Studies, 7(1), 49-59.

Norris, F. (2016). The pathway to proficiency: the role of grammar in second language teaching and learning. Unpublished Doctoral Dissertation, Baylor University. 
Akdağ Çimen, B. (2017). Turkish EFL lecturers' perceptions regarding the essentials in a high-quality foreign language education. International Journal of Social Sciences and Education Research, 3(5), 1606-1615.

Panther Bishoff, J. (2010). Utilization of the Seven Principles for Good Practice in Undergraduate Education in General Chemistry by Community College Instructors. Published Doctoral Dissertation, West Virginia University.

Pate-Clevenger, R., Dusing, J., Houck, P., \& Zuber, J. (2008). Improvement of off-task behavior of elementary and high school students through the use of cooperative learning strategies. (ERIC Document Reproduction Service No. ED500839).

Pattanapichet, F., \& Wichadee, S. (2015). Using Space in Social Media to Promote Undergraduate Students' Critical Thinking Skills. Turkish Online Journal of Distance Education, 16(4), 38-49.

Ph'ng, L. M., Ming, T. S., \& Nambiar, R. M. (2015). MATCHING TEACHING STYLES AND LEARNING STYLES: WHAT HAPPENS IN THE CASE OF A MISMATCH?. e-BANGI, 10(1), 66-76.

Rimm-Kaufman, S. E., Baroody, A. E., Larsen, R. A., Curby, T. W., \& Abry, T. (2015). To what extent do teacher-student interaction quality and student gender contribute to fifth graders' engagement in mathematics learning?. Journal of Educational Psychology, 107(1), 170-185.

Salahshour, N., \& Hajizadeh, N. (2013). Characteristics of effective EFL instructors. Procedia-Social and Behavioral Sciences, 70, 163-173.

Sparapani, E. F. A., \& Perez, D. M. C. (2015). Perspective on the Standardized Curriculum and Its Effect on Teaching and Learning. Journal of Education \& Social Policy, 2(5), 78-87.

Skipper, Y., \& Douglas, K. (2015). The influence of teacher feedback on children's perceptions of studentteacher relationships. British Journal of Educational Psychology, 85(3), 276-288.

Slavin, R. E. (1985). An introduction to cooperative learning research. In Slavin, R.E., Sharan, S., Kagan, S., Hertz-Lazarowitz, R., Webb, C., \& Schmuck, R. (Eds.) Learning to cooperate, cooperating to learn (pp. 5-15). Springer US.

Taylor, L. (2016). Using active learning activities to enhance student engagement in a business English program. Papers on Postsecondary Learning and Teaching, 1, 27-32.

Thomson, N. (2012). Language teaching strategies and techniques used to support students learning in a language other than their mother tongue (Jeff Thompson research paper). London: International Baccalaureate Organization.

Tulbure, C. (2011). Do different learning styles require differentiated teaching strategies?. Procedia-Social and Behavioral Sciences, 11, 155-159.

Tulung, G. J. (2008). Communicative task-generated oral discourse in a second language: A case of peer interaction and non-native teacher talk in an EFL classroom. Unpublished Doctoral Dissertation, University of Ottawa.

Varghese, S. (2016). A quantitative study on online student faculty interaction and learning experience (Order No. 10252984). Available from ProQuest Dissertations \& Theses Global. (1870786030). Retrieved on 11.04.2017 from https://search.proquest.com/docview/1870786030?accountid=8403

Walkey, F. H., McClure, J., Meyer, L. H., \& Weir, K. F. (2013). Low expectations equal no expectations: Aspirations, motivation, and achievement in secondary school. Contemporary Educational Psychology, 38(4), 306-315.

Yassin, B. M., \& Almasri, M. A. (2015). How to Accommodate Different Learning Styles in the Same Classroom: Analysis of Theories and Methods of Learning Styles. Canadian Social Science, 11(3), 2633. doi: $10.3968 / 6434$

Zamani, M. (2011). Cooperative learning: Homogeneous and heterogeneous grouping of Iranian EFL learners in a writing context. Unpublished Master Thesis, Allameh Tabataba'i University. 